\title{
APPROACH OF CHRISTIAN THOUGHT TO ISLAM IN THE MIDDLE AGES: EXAMPLES OF BERNARD OF CLAIRVAUX, PETER THE VENERABLE, FRANCIS OF ASSISI AND THOMAS AQUINAS
}

\author{
Yasin İPEKa
}

\begin{abstract}
Christian and Muslim relationships went through different processes in the $12^{\text {th }}$ and the beginnings of $13^{\text {th }}$ century. The Papacy and Bernard of Clairvaux had adopted negative attitude toward Islam and Mohammad at the time of crusade. It can be described as an antagonism in the best way. Peter the Venerable had become a more different approach. He wanted to convert Muslims with a more objective attitude by emphasizing to the words, the reasons, and the love, not to the weapons, the force and the hatred. The invitation of Peter to the words, the reasons and love gained a new dimension with Francis of Assisi. He appears as the key figure in transition missionary activities towards the Muslim world. That is why he has been called as model for human liberation, the peaceful crusader and friends of Muslims by some researchers and scholars. As for some researchers, he was a model for the conversion of Muslims and not a model for friends of them. Thomas Aquinas had engaged in scientific missionary activities and pointed out a negative manner towards Muslims and Islam. The aim of the essay is to assess the view of medieval Christianity toward Islam in the context of Bernard of Clairvaux, Peter the Venerable, Francis of Assisi and Thomas Aquinas.
\end{abstract}

Keywords: History of Religions, Islam, Bernard of Clairvaux, Peter the Venerable, Francis of Assisi, Thomas Aquinas.

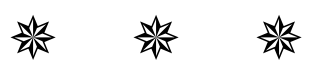

a Asst. Prof., Kayseri University, yasinipek@kayseri.edu.tr 
Yasin İPEK

\section{ORTA ÇAĞ'DA HIRISTIYAN DÜŞÜNCESIININ İSLAM'A YAKLAŞIMI: BERNARD OF CLAIRVAUX, PETER THE VENERABLE, FRANCIS OF ASSISI VE THOMAS AQUINAS ÖRNEKLERI}

Tarihsel süreçte Hıristiyanlarla Müslümanların ilişkileri farklı mahiyetlerde süregelmiştir. Geniş bir zaman dilimini kapsayan bu süreç içerisinde özellikle 12 . ve 13. yüzyıllar da yaşananlar dikkat çekicidir. Papalık ve Bernard of Clairvaux, haçlı seferleri sırasında İslam ve onun peygamberi Muhammed'e karşı olumsuz bir yaklaşım tarzı sergilemiştir. Onların benimsemiş oldukları bu tavrı belki de en güzel şekilde ifade edecek olan kavram antagonizmdir. Peter the Venerable ise bu konuda daha farklı bir yaklaşım tarzı sergilemiştir. 0 , Müslümanlara karşı kin, baskı ve nefret yerine sözler, akıl ve sevgi ile yaklaşılması gerektiği hususuna vurgu yaparak konuyu daha nesnel bir hale dönüștürmek istemiștir. Peter'in sözü, aklı ve sevgiyi teşvik eden bu daveti Francis of Assisi ile yeni bir boyut kazanmıştır. 0 Müslüman dünyaya doğru misyoner faaliyetlerin başlamasında anahtar bir figür olarak önemli bir rol oynamıștır. Bu yüzden bazı araștırmacı ve akademisyenler tarafından o, insan özgürlüğünün bir modeli, barışçıl haçlı savaşçısı, hatta Müslümanların dostu olarak isimlendirilmiștir. Fakat böyle düşünmeyen diğer araştırmacılara göreyse o, Müslümanların dostu değil, onların dönüştürülmesi için bir modeldir. Bunların dışında Thomas Aquinas ise bilimsel açıdan misyonerlik faaliyetleri ile meşgul olmuş, Müslümanlara ve İslam’a karşı o da olumsuz bir tavır sergilemiştir. Bu makalenin amacı Bernard of Clairvaux, Peter the Venerable, Francis of Assisi and Thomas Aquinas'ı merkeze koyarak Orta Çağ Hıristiyanlarının İslam dinine ve Müslümanlara olan bakışları analiz etmektir.

[Geniş Türkçe öz makalenin sonunda yer almaktadır.]

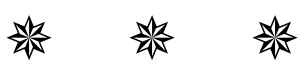

\section{Introduction}

The approach of Medieval Christian thought towards Islam and Muslims, especially $12^{\text {th }}$ century and the beginnings of $13^{\text {th }}$ century went through different processes. While some used detestation language, the others put to use a moderate attitude. Bernard de Clairvaux (d. 1153), Peter the Venerable (d. 1156), Francis of Assisi (d. 1226) and Thomas Aquinas (d. 1274) are among the important religious identities that stand out with their different approaches in this process. Bernard de Clairvaux was a Burgundian abbot. He was a major leader in the re-aousal of Benedictine monasticism by means of the Order of Cistercians. In addition to his monastic work, he made great efforts to explain his unique vision of god and defend the church

|316| through his travels in Western Europe. He gave sermon about the crusades against Muslims as a reflection of the Pope's appreciation and advisory duty 
(Zerbi, 2003: 307-308). Peter the Venerable was the abbot of the Benedictine abbey of Cluny. He took part in many of the international religious councils as a partner of national and religious leaders. He gathered many sources about Islam. He held long religious negotiations with Islamic scholars of all levels (Auguste, 1911). St Francis of Assisi was a Roman Catholic friar and the founder of the Orders of Friars Minor known as Franciscans. After listening the Sermon about Matthew 10:9 in 1209, Francis decided to dedicate himself to a life of poverty and he tried to serve to the Lord by preaching until he died. He established the rule of Assisi which has been presented as the order of Assisi or the Franciscans. With this order, he adopted peaceful resolution, dialogue and human liberation towards Muslims and Islam in the course of the fifth crusade. As for Thomas Aquinas was the Dominican saint, philosopher, and church doctor who made great contributions to scholastic thought on topics such as philosophy of knowledge and metaphysics. On the one hand, he revealed the influence dimension of Islamic thought on the European Christian mentality, on the other hand, he determined its limits. He presented cursing and wicked language against Muslims and Islam (Goddard, 2000/2018). Our aim in this article is to give information about the approach of Medieval Christianity towards Islam in the light of the views of The Papacy and Bernard of Clairvaux, Peter the Venerable, Francis of Assisi and Thomas Aquinas.

\section{A. The Papacy and Bernard of Clairvaux: Crusaders and The Invitation of Confederation}

The papacy, at the time of crusades, had adopted negative attitude toward Islam and Muhammad. It can be described as an antagonism in the best way (Hoeberichts, 1997). The reason for this attitude was that Islam had rapidly begun to rise up in the west in the 12 th and 13 th centuries, and it was necessary to prevent this rising, and to take serious precautions in the face of the advance of Islam (Moorman, 1968). The first thing which had been carried out became to make provision for the Holy War by bringing together crusaders (Chapman, 1997) and to commence European military action against the Muslim world in a manner which was filled with grievance, hostility and fundamentalism (al-Sharif, 1999). The method which had been used that to fight against the Muslims with soldiers on the one hand, to use very negative language against Mohammad, the Quran and Islamic values on the other.

One of these movements against Islam became to constitute the Templar Order (Knights Templar) which was established in 1119 by nine 
noble knights. The order was founded for defensive purposes, such as protecting pilgrims while they were going to and from Jerusalem. Furthermore, it gave countenance to massacre the Muslims and other infidels by entitling the name of this war as holy violence, legitimate war, and warfare against infidels. The pamphlet which was prepared by Bernard of Clairvaux became the most aggressive statement of combatant Christianity and in a manner of speaking; it was a sanctification of crime. While he was trying to regenerate peace in Christendom on the one hand, he was mixing religion with military services on the other. Bernard's doctrine was that nonChristians should be killed for eradicating the evil. However, Bernard announced peace in everywhere for bringing together Christian World against their enemies. Because according to him, as long as the whole Christian world did not come together, they couldn't win the battle against Muslims (Mastnak, 2002). As a result, the invitation which had been done by Bernard concluded by making certain the participation in the Second Crusade (Goddard, 2000/2018).

The William of Tyre had especially disposed some arguments against Mohammad by characterizing him as a seducer, the first birth of devil and against his teachings and by defining him as depraved teachings (Hoeberichts, 1997).

As for Innocent III, his goal was to liberate the Holy land from their enemies and to rescue the slaves in the hands of the enemy from enslaving them. He had described Mohammad as the son of damned and Muslims as cruel, brutal, atrocious, and bloodthirsty barbarians and showed the greatest enemy of Christianity (Hoeberichts, 1997).

Cardinal Hugolino who had taken Innocent's III place had continued same statements against Islam. Moreover, he had tried to bring together the Christian kings and nations by restoring peace between them and collecting money and men against the Muslim world (Hoebericths, 1997).

All these statements, and general view at that time, especially until Peter the Venerable, pointed out that the Christian preachers invited every Christian to fight with arms and swords against the Muslims and expand Christendom in this way. According to Thomas Cahill; (Cahill, 2007), "The most visible signs of the Christian religion were the wars and atrocities of the red-crossed crusaders..." (St. Francis: The peaceful crusader division, para. 1).

\section{B. Peter the Venerable: Translation Activities}

While the rationale of the conversion and conquest had only been set 
up upon fighting, swords and soldiers, Peter the Venerable had become a more different approach's pioneer by preferring reason to violence though he did not oppose the Crusades (Goddard, 2000/2018). The first thing which he did became translation activities of some Arabic books and especially the Qur'an into Latin (Mastnak, 2002). A lot of Arabic books were translated as a part of this purpose such as al-Kindi's Apology and the Quran. This was the first translation of the Qur'an to Latin by Robert of Ketton (Goddard, 2000/2018). These works have been accepted as the origin of Islamic and Oriental Studies. His main purpose was to enlighten the Christian world about Islam and to refute it. According to him, it would be easier to refute Islam if the Christian world knew Islam and its principles (Hoeberichts, 1997).

Peter wanted to convert Muslims with a more objective attitude by emphasizing to the words, the reasons, and the love, not to the weapons, the force and the hatred (Matsnack, 2002). Thusly Peter said:

"I don't attack you, as some of us often do, by arms, but by words; not by force, but by reason; not in hatred, but in love. Obedient to divine instruction and to human nature endowed with reason that is 'known to love what is like himself' he loved them and loving, I write to you; writing, I invite you to salvation." (Kritzeck, 1964: 145).

However, Islam stayed still the hostile religion which was necessary to be refuted and perished (Hobericths, 1997).

Though Peter the Venerable embraced Muslims lovingly, he displayed the attitude of his predecessors against Mohammad, describing him as the spokesperson and son of the devil and portraying his teachings as completely unrealistic and full of errors. In addition, for him, Islam is an unholy humanmade doctrine, the sum of heresies and so on. In short, Peter used a very negative language against Mohammad and Islam (Kritzeck, 1964; Hobericths, 1997; Matsnak, 2002).

However, instead of fighting, Peter sought to divert Christians' interests into converting Muslims by having the Qur'an and other important Islamic works translated and refuted them. Its purpose is thought to be to implement two basic principles: to eliminate ignorance about Islam and to refute Islamic values (Goddard, 2000/2018). Standing out as a man of peace at that time, Peter displayed a more objective attitude by opening the door of tolerance and by using Islamic terminology and showing similarities between Christianity and Islam (Kritzeck, 1964). Although he disliked Islam 
Yasin İPEK

and Muslims like his contemporaries and wanted Christianity to spread everywhere, he at least invited Christians to words and love (Mastnak, 2002).

\section{Francis of Assisi: The Representative of Peace and Compassion}

His approach had a different place among his contemporaries (Sabatier, 1899/1919). For this reason, some researchers and scholars called him as model for human liberation (Boff, 1985), the peaceful crusader (Cahill, 2007; Mastnak, 2002), friend of Muslims (Al-Sharif, 1999), as a model for interreligious dialogue (Cunningham, 2006). However, some researchers such as Frank Rega said that Francis Assisi was a model for missionary activities and the conversion of Muslims, not a model for friends of Muslims (Rega, 2007).

The invitation of Peter the Venerable to words and reason, to love and missions towards Muslims took a new dimension with Francis of Assisi. He appears to be a key figure in transition missionary activities toward the Muslim world (Goddard, 2000/2018). The military forces were replaced by missionary activities with Francis and his brothers (Chesteron, 1951). Assisi described himself and his brothers as peacemakers in the light of the Gospel of Mathew: "Blessed are the peacemakers, for they shall be called the children of God" (Mathew 5/9).

Francis who tried to win the hearts of humans instead of fight (Chapman and Robson, 1997), decided to take peace and to broaden Christian missionary in everywhere in the world, especially to the Muslims and the Muslim (Hoebericths, 1997; Turan, 2011: 47). They have been accepted as a practitioner of peace with this amicable approach (Mastnak, 2002). The ecumenical values which St Francis put into effect in his missionary activity was poverty, minority and peace (Boff, 1985).

Although the aims of both the Crusaders and the missionaries were the expansion of Christendom, it seems to me that Saint Francis's invitation to peace and renounce violence and war is a crucial development for peace and dialogue. Francis of Assisi made three attempts to go to the Holy Land in order to put his teachings into practice. His first attempt failed because the ship he was on was unable to sail due to the wind. A few years later, his second attempt was interrupted due to illness. St Francis, who did not back down from his ambition, reached the Holy Land in 1219 while the fifth crusade was being made (Chapman and Robson, 1997).

Why did Francis go to the Muslims and what was his main goal? At that time Christian world was asking for standing out against the growth of Islam in the west. Because of this, they had launched the Crusades. However, it was 
sought different solutions such as missionary activities. In this context, the missionary activity among the Muslims and other non-believers was voiced at the opening of the Forth Lateran Council and its canon 71. Paying attention to this invitation from the Papacy, Francis emerged as the leader of the church's modern missionary activity (F. Assisi and C. Assisi, 1982).

It is understood that Francis had gone to the Muslims as an officer of the papacy instead of behaving alone. With Francis of Assisi, the Papacy's approach to the Muslim world had transformed from one-sidedness to a double character as missionary and crusade. He asked the Pope with his eleven brothers to create a new monastic world under Christianity by transforming the Muslim world (Chesteron, 1951; Bosch, 2004).

As for his main goal, it is considered two different approaches. One of them said that St Francis's main goal was to open ways of contact of dialogue with the Muslims and to establish true peace between two groups (Hoeberichts, 1997; Batuk, 2012:253). According to James M. Powell, one of the prominent masters on Francis of Assisi and the Fifth Crusade, "Francis of Assisi went to Damietta on a mission of peace. There can be no question about this. We shouldn't, however, try to make him a pacifist or to label him as a critic of the Crusade." (Rega, 2007: 63). As for the other side, the main goal was to carry through crusader to the conclusion and to ensure the achievement of their purpose and to create Christianity by preaching to the Muslims and converting them rather than destroying (Chesteron, 1951). Moreover, Christopher Maier, who was one of the major Crusade scholars, asserted that: "Francis thus accepted the Crusade as both legitimate and ordained by God, and he was quite obviously not opposed to the use of violence that it came to the struggle between Christians and Muslims" (Rega, $2007 ; 70$ ).

Francis wanted to establish missionary province in the Middle East and liberate the Holy land from Muslim rule (Rega, 2007). However, all sources pointed out that his main goal was to convert the Sultan and become a martyr in the holy land. T.W. Arnold has showed his main goal in the Little Flowers of Assisi by this statement: "By zeal for the faith of Christ and the desire for martyrdom" (Arnold, 1904; 71).

As much as his purpose is very important, the methodology which he carried out for achieving his goal is more significant than his purpose. Because he had been the pioneer of a new approach, of a peaceful manner instead of violence, and tried to show the success of this approach by living among the Muslims. 
It is considered that Francis had constituted his method on the basis of the Gospel. The Rule of 1221, Chapter 16 by the title Missionaries among the Muslims and other unbelievers in Writings of Francis manifests his methodology which had especially paid attention to two points: First of all is to keep away from quarrels, arguments and disputes and "be subject to every human creature for the God's sake" (1 Pet. 2:13) (F. Assisi, 1960/1979). Francis wanted to pay attention to the importance of obedience to the Spirit and the rejection of violence and power with being subject. Additionally, he invited all people to establish a new world being based on love, brotherhood, compassion and kindness (Hoeberichts, 1997).

The second way is to;

"proclaim the word of God openly, when they see that is God's will, calling on their hearers to believe in God almighty, Father, Son, and Holy Spirit, the Creator of all, and in the Son, the Redeemer and Saviour, that they may be baptized and become Christians, because unless a man be born again of water, and the Spirit, he can't enter into the kingdom of God (Jn 3:5)" (F. Assisi, 1960/1979; 43).

He wanted to call attention to the superiority of Christianity, especially with the sentence beginning with they may be baptized ..., the points which will be stressed while friars was speaking about God, Son and Holy Spirit (Hoebericths, 1997).

Additionally, St Francis advised his brothers that they should be meek, patient, courteous (Chapman and Robson, 1997), and live within the Muslims as an example of Christian living (Moorman, 1950). And they should preach the love of Christ (Bedoyere, 1962), the holiness of a life which is full of love of Christ (Sabatier, 1899/1919). And they should behave definitely positive and represent actively the proclamation of the Gospel and not condemn and criticize Islam itself (Rega, 2007). Wherever they went, the first thing they would say "The Lord give you peace" (F. Assisi, 1960/1979; 68).

It is considered that he might have wanted to show the importance of peaceful manner and religion emphasis in conversion-oriented activities. Because he knew that dispute, competition, and conflict would influence negatively the opponent instead of persuading, and may be, would enhance hatred. Furthermore, he knew that the five friars who went to Morocco had died because they conducted disputatiously, antagonistically, aggressively, and always insulted Muhammad and the Quran and Islamic values in everywhere (Vennari, 2007). As a result, it seems to me, his methodology is not apologetic or defensive; it is a persuasive by living the pure and chaste 
within the Muslims and showing the reality of Christianity.

St Francis decided to go to the Sultan Malek al-Kamil for carrying out his main goal, martyrdom or the conversion of the Sultan. Because, according to him if the Sultan converted his religion, his people might be converted also (Goudge, 1961). Most of sources did not say anything regarding how Francis reached the Sultan. According to Moorman, this is a mystery: "How he ever reached the Sultan's presence is a mystery which can never be solved" (Moorman, 1950, 45).

It is considered that Francis went to the Sultan with some soldiers, at least up to the border. Because no commander would ever allow such an important person to be sent alone without any protection. Because no commander would ever allow such an important person to be sent alone without any protection. It is also interesting that the time when Saint Francis reached Damietta coincided with the period proposed by the Sultan (from 29 August to 26 September) (from 29 August to 26 September) (F. Assisi, 1960/1979; Rega, 2007). Saint Francis sought permission from Pelagious to meet the Sultan and invite him to the Bible, and Pelagious had sent Saint Francis to the Sultan under the banner of peace (Runciman, 1955). The attempt to end the war by transforming the Sultan at that time can be considered an important development. It is also believed that the Sultan's soldiers did not torture and misbehave as Bonaventura stated in Major Life. Another important point is that the Muslims of Francis and Brother Illuminato answered: "I am Christian; He met with your master." (F. Assisi, 1960/1979). When the Qur'an is analysed, the following verse will be seen this verse:

"Certainly, you will find the most violent people in enmity for those who believe (to be) the Jewsand those who are polytheists and you will certainly find the nearest in friendship to those who believe (to be) those who say: we are Christians; this is because they are priests and monks among them and because they don't behave proudly..." (Al-Ma'idah 5/82).

Whether Francis could know this verse or not is not certain, however, it is obvious that this answer had affected the Sultan who knew the Quran.

Francis who was entertained very well by Malek al-Kamil attempted to convert the Sultan by preaching to him the Christian faith (Cunnigham, 2006). Bonaventure expressed that Francis challenged to the Sultan and his fellows with the ordeal of fire to show his truthfulness (F. Assisi, 1979). It seems to me that he was challenged by the ordeal of the fire because he was 
not fit to act in a way that would create a negative environment for a person who forbids quarrel and conflict. Likewise, Sabatier said that: "Ordeal of fire which comes from Bonaventure, perhaps, is born of misconception..." (Sabatier, 1899/1919; 230).

It could be considered that Bonaventure had dealt with the matter by an honorific approach.

Jacques De Vitry made the following statements in Sermon: "One day the Sultan wanted to test the faith and fervour that Blessed Francis manifested toward our crucified Lord. He had a beautiful multicoloured carpet spread out on the ground..." (F. Assisi, 1960/1979; 1614).

And also, it was narrated another story the Sultan asked Francis: "Your Lord taught in his gospels that evil must not be repaid with evil that you should not refuse your cloak to anyone who wants to your tunic ..." (F. Assisi, 1979; 1614-1615).

As for Jacques de Vitry, Francis gave this answer to the Sultan in the course of dialogue:

"If your eye causes you to sin, tear it out and throw it away (Matthew 5, 29) ... That is why it is just that Christians invade the land you inhabit, for you blaspheme the name of Christ ..., but if you were to recognize, confess and adore the Creator and Redeemer, Christians would love you as themselves..." (F. Assisi, 1960/1979; 1615).

It is thought that this approach is more compatible with Francis' methodology rather than Bonaventure's. Inasmuch as Francis had openly proclaimed the Gospel and didn't attack Islam itself. However, there is a rejection of Islam inexplicitly and confirmation of crusade in terms of target, to cease the progress of Islam and to convert the Muslims to Christianity, not in terms of method which was fulfilled by crusaders.

Whether these two stories were real or not, this is the fact that Francis, Brother Illuminato, the Sultan and a group of Muslim scholars had spoken about their beliefs each other and sought the dialogue on the principle of ending violence and ensuring peace among people (al-Sharif, 1999). Francis was against Islam; however, he might have been affected the honoured character of the Sultan and Muslims' practices such as daily ritual worship, the people's public commitment to prayer (Little, 1897). In addition, the Sultan had been influenced from his pure and understanding life which was full of love while they were communicating (Smith, 1972). This means that both of them impressed one another. It can be evaluated in this context that 
Francis had never used negative language concerning Islam, Muhammad and Islamic values like the formers. Additionally, according to Thomas Cahill:

(Cahill, 2007), "It is quite possible that the thrice-daily recitation of the Angelus that became current Europe after this visit was precipitated by the impression made on Francis by the call of the Muezzin just as the quintessential Catholic devotion of the rosary derives from Muslim prayer beads..." (St. Francis: The peaceful crusader division, para. 3).

Moreover, it appears to me that the statement of "God give you peace" resembles the word of the Muslims "as-salaam aleykum-peace be upon you". May be, this can be evaluated as an evidence relating to be influenced.

As for the Sultan had given permission to them for preaching whatever they wished and also sent some soldiers with them for protecting against attacks until the border (Mastnak, 2002). And although the crusader army was defeated after the fifth crusade, the sultan released thirty thousand Christian prisoners (Rega, 2007). It seems to me that this shows the peaceful attitude of the Sultan and the sultan's positive response to the positive attitude of Francis.

Considering the martyrdom of Francis, or the conversion of the sultan, these two desires could not be achieved. Bonaventure stated that he could not achieve his goal in the following words: "Besides he could see no sign of a genuinely religious spirit in the Sultan and realized that there was no hope of converting the Muslims and that he could not win the crown of martyrdom..." (F. Assisi, 1979; 705).

According to Little Flowers the Sultan converted the Christianity with these words: "Brother Francis, I would willingly be converted to the faith of Christ..., show me how can I achieve salvation, and I am ready to obey you in everything..." (F. Assisi, 1979, 1355-1356).

There is no evidence as to whether the sultan had converted, except in Bonaventure's Great life. It seems the same to me for Frank Rega, the Sultan's deathbed transformation must be a story that is not based on reality (Rega, 2007).

\section{Thomas Aquinas: The Scientific Crusader}

The Franciscan movement, initiated by Francis of Assisi, emphasized a dialogue based on compassion and winning hearts, while the Dominicans aimed to gain intelligence and minds (Mastnak, 2002). Thomas Aquinas (1225/1274), the foremost Dominican and the greatest Christian theologian of medieval, learned Islam from his companions, earlier Christian writings, 
and the works of Farabi, Avicenna and Ibn Rushd (Waltz, 1976; 81-95). It is possible to see the effects of Islam and Greek philosophy in the works of Thomas Aquinas who studied Aristotle at the same time (Goddard, 2000/2018). However, Aquinas, who saw the Muslims and other infidels as a single enemy wrote a small treatise, the first missionary book against Muslims. His main reason for writing this book was to assist Christians living in Muslim lands in their conversion. Aquinas, who took an intellectual approach to missionary work against the Franciscans, was the starting point: "Always be ready to give an answer who ask you a reason of the hope and faith that is in you..." (Mastnak, 2002; 210).

This reflects of the philosophy of Thomas Aquinas "to demonstrate the reasonableness of Christian faith rather than proving of faith". Inasmuch as according to him; "Christian controversialists should not try to prove their faith, because faith cannot be proved" (Mastnak, 2002; 210).

Despite his opposition to war, he tried to prove this by using cursing and wicked language at Muslims. Muslims responded to this attitude by denying the Trinity, the Divinity of Christ, or the saving act of Christ's death (Mastnak, 2002). For Aquinas; “Islam's very existence, hindering as it did the spread of Christianity, could be construed as a legitimate cause for Christian warfare" (Kedar, 1984; 183-184).

Additionally, Aquinas had followed the path of formers such as Peter the Venerable by insulting Mohammad and the Islamic values. In the Summa Contra Gentiles, he attacks Mohammad:

"Mohammad enticed peoples with the promise of carnal pleasures, to desire of which the concupiscence of the flesh instigates. He also delivered commandments in keeping with his promises, by giving the reins to carnal pleasure, wherein it is easy for carnal men to obey ..." (Aquinas, 1924; 13).

As a result, Aquinas engaged in scientific missionary activities and supported and displayed a negative attitude towards the crusaders' attitude towards Muslims.

\section{Conclusion}

As can be seen from the above explanations, the thoughts, behaviours and the language of Christian religious leaders against Muslims and Islam showed itself with different aspects. In addition to using extremely negative language, Bernard also appears to be a strong supporter of the Crusades. Therefore, he both created a negative perception about Islam in the eyes of Christians and prepared the ground for the continuity of Crusades. Peter, 
however, took a different approach to Islam and Muslims than Bernard. This is due to his different understanding of Christianity. While supporting the Crusades, its basic philosophy had been to examine and recognize the religion of Islam from its own sources comprehensively and to refute the Islamic teaching. Although he has a positive tendency, the language he uses against Islam, especially Mohammad, is insulting. Looking at Assisi's philosophy based on love and tolerance, it can be expressed as a radical alternative to the Crusader thought of that period. He aimed to win hearts towards Jesus rather than gaining land with the Crusades. He appears as the first person to initiate systematic missionary activities and dialogue with Muslims in Islamic lands. As for Aquinas, the extent of Islamic influence is clear in his thought as a reflection of Islamic philosophy. It is seen that he created defensive works aimed at the correctness of the Catholic belief against Muslims. Like Peter, he did not refrain from using insulting language against Mohammad and Islam.

\section{BIBLIYOGRAPHY}

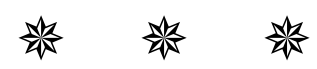

AL- SHARIF, A. (1999, Kasım 24). Interfaith dialogue, a possibility for peacemaking. 15 Ekim 2020 tarihinde http://hiwarnet.usj.edu.lb/chroniques16.htm/ adresinden erişildi.

ALMEDINGEN, E. M. (1967). Francis of Assisi: A portrait. London: The Bodley Head.

AQUINAS, T. (1924). The summa contra gentiles of Saint Thomas Aquinas I. London: Burns, Oates and Washbourne.

ARNOLD, T.W. (1904). The little flowers of St. Francis. London: J.M. Dent.

ASSISI, F. (1979). St. Francis of Assisi, writings and early biographies: English omnibus of the sources for the life of St. Francis. (3. ed.). M. A. Habig (Ed.). R. Brown (Trans.). London: S.P.C.K. (1960).

ASSISI, F. and ASSISI, C. (1982). Francis and Clare: The complete works. R. J. Armstrong (Ed.). New York: Paulist Press.

AUGUSTE, F. P. (1911). Blessed Peter of Montboissier. The Catholic Encyclopedia. (Vol. 10). New York: Robert Appleton Company. 01 Ekim 2020 tarihinde https://www.newadvent.org/cathen/10525b.htm adresinden erişildi.

BATUK, C. (2012). Assisili Francis ve Hiristiyan Mistisizmi. İstanbul: İz Yayıncillk. 
BEDOYERE, M. (1962). Francis: A biography of the Saint of Assisi. New York: Harper and Row Publishers.

BOSCH, D. J. (2004). Transforming Mission. 19. Baskı. New York: Orbis Books.

BOFF, L. (1985). Saint Francis: A model for human liberation. London: SCMCanterbury Press.

BROOKE, R. B. (1970). The writings of Leo, Rufino and Angelo companions of St. Francis. Oxford: The Clarendon Press.

CAHILL, T. (2007, Şubat 2). Debate: St. Francis of Assisi and Islam. 15 Ekim 2020

tarihinde http://guardduty.wordpress.com/2007/01/02/debate-st-francis-ofassisi-and-islam/ adresinden erişildi.

CHAPMAN, G. and ROBSON, J. P. M. (1997). St. Francis of Assisi: The legend and the life. London: Geoffrey Chapman.

CHESTERON, G. K. (1951). St. Francis of Assisi. London: Hodder and Stoughton.

CUNNINGHAM, L. (2006, Ocak 19). Francis of Assisi as a catholic saint. 15 Ekim $2020 \quad$ tarihinde http://muse.jhu.edu/journals/logos/v009/9.1cunningham.html/ adresinden erişildi.

GODDARD, H. (2018). Ortaçağdan günümüze Hıristiyan Müslüman ilişsileri tarihi. Şükrü Alpagut (Çev.). İstanbul: Say Yayınları. (2000).

GOUDGE, E. (1961). Saint Francis of Assisi. London: Hodder and Stoughton.

HOEBERICHTS, J. (1997). Francis and Islam. Quincy: Quincy University Press.

KEDAR, B. Z. (1984). Crusade and mission: European approaches toward the Muslims. Princeton: Princeton University Press.

KRITZECK, J. (1964). Peter the venerable and Islam. Princeton: Princeton University Press.

LITTLE, W. J. K. (1897). St. Francis of Assisi- His time, life and work: Lectures delivered in substance in the ladye chapel of worcester cathedral in the lent of 1896. London: Isbister.

LONGFORD, F. P. (1978). Francis of Assisi: A life for all season. London: Weidenfeld and Nicolson.

MASTNAK, T. (2002). Crusading peace-Christendom, the Muslim world and western political order. London: University of California Press. 
MOORMAN, J. (1968). A history of the Franciscan order: from its origins to the year 1517. London: Oxford University Press.

REGA, F. (2007). St. Francis of Assisi and the conversion of the Muslims. Illinois: Tan Books and Publishers.

RUNCIMAN, S. (1955). A History of the crusades: The kingdom of acre and the later crusades 3. Cambridge: Cambridge University Press.

SABATIER, P. (1919). Life of St. Francis of Assisi. L. S. Houghton (Trans.). London: Hodder and Stoughton. (1899).

SMITH, J. H. (1972). Francis of Assisi. London: Sidgwick and Jackson.

TURAN, S. (2011). Misyoloji: Hıristiyan Misyon Bilimi. İstanbul: Sarkaç Yayınları.

VENNARI, J. (2007, Şubat 2). Debate: St. Francis of Assisi and Islam. 15 Ekim 2020 tarihinde http://guardduty.wordpress.com/2007/01/02/debate-st-francis-ofassisi-and-islam/ adresinden erişildi.

WALTZ, J. (1976). Muhammad and the muslims in Thomas Aquinas, Muslim World, 56, 81-95.

ZERBİ, P. (2003). Bernard of Clairvaux. New Catholic Encyclopedia (2. ed.), 2, 307-308.

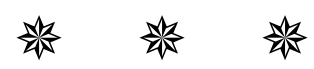




\title{
ORTA ÇAĞ'DA HIRİSTIYYAN DÜŞÜNCESİNIN ISLAM'A YAKLAŞIMI: BERNARD OF CLAIRVAUX, PETER THE VENERABLE, FRANCIS OF ASSISI VE THOMAS AQUINAS ÖRNEKLERİ
}

\author{
Yasin İPEKa
}

\section{Geniş Öz}

Hıristiyan Müslüman ilişkileri 12. ve 13. yüzyıllarda farklı süreçlerden geçmiştir. Bazıları nefret dilini kullanırken, diğer bazısı ılımlı bir tutum sergilemişlerdir. Bernard de Clairvaux, Peter the Venerable, Francis of Assisi ve Thomas Aquinas bu süreçte farklı yaklaşımları ile öne çıkan önemli dini kimliklerdendir. Bernard, Burgonyalı bir başrahipti. Manastır çalışmalarına ek olarak, Batı Avrupa seyahatlerinde tanrı vizyonunu açıklamak ve kiliseyi savunmak için büyük çaba gösterdi. Papa'nın takdir ve danışmanlık görevinin bir yansıması olarak Müslümanlara karşı haçlı seferleri hakkında vaaz verdi. Haçlı seferleri sırasında papalık, İslam'a ve Muhammed'e karşı olumsuz bir tutum benimsemişti. En iyi şekilde bir antagonizm olarak tanımlanabilir. Bu tavrın nedeni, İslam'ın 12. ve 13. yüzyıllarda batıda hızla yükselmeye başlaması ve İslam'ın ilerleyişi karşısında ciddi önlemler alınması gerektiğiydi. Bu süreçte kullanılan yöntem bir yandan askerlerle Müslümanlara karşı savaşmak, diğer yandan Muhammed'e, Kuran'a ve İslami değerlere karşı çok olumsuz bir dil kullanmak olmuştur. Bernard tarafından hazırlanan broşür, savaşan Hıristiyanlığın en agresif ifadesi oldu ve bir anlamda suçun kutsal kılınmasıydı. Bir yandan Hıristiyan aleminde barışı yeniden tesis etmeye çalışırken, diğer yandan dini askeri hizmetlerle karıştırıyordu. Bernard'ın öğretisi, kötülüğü ortadan kaldırmak için Hıristiyan olmayanların öldürülmesi gerektiğiydi. Peter the Venerable Cluny Benedict manastırının başrahibiydi. Birçok uluslararası dini konseyde yer

a Dr. Öğr. Üyesi., Kayseri Üniversitesi, yasinipek@kayseri.edu.tr 
aldı. İslam hakkında pek çok kaynak topladı. Her seviyeden İslam alimleriyle uzun dini görüşmeler yaptı. Kilise ve Bernard'ın tövbe ve fetih mantığı sadece her Hıristiyanı Müslümanlara karşı silah ve kılıçla savaşmaya ve Hıristiyan âlemini bu şekilde genişletmeye daveti üzerine kurulurken, Peter, Haçlı Seferleri'ne karşı çıkmadığı halde aklı şiddete tercih ederek daha farklı bir yaklaşımın öncüsü haline gelmişti. Yaptığı ilk şey pek çok Arapça kitabın ve özellikle Kur'an'ın Latinceye tercümesi oldu. Bu Kur'an'ın Latinceye ilk tercümesidir. Asıl amacı, Hıristiyan dünyasını İslam hakkında aydınlatmak ve onu çürütmekti. Peter silahlara, kuvvete ve nefrete değil, sözlere, nedenlere ve sevgiye vurgu yaparak Müslümanları daha objektif bir tavırla dönüştürmek istedi. Ancak İslam, reddedilmesi ve yok edilmesi gereken düşmanca din olarak kaldı. Peter, Müslümanları sevgiyle kucaklasa da, seleflerinin Muhammed'e karşı tavrını sergiledi, onu şeytanın sözcüsü ve oğlu olarak tanımladı ve öğretilerini tamamen gerçek dışı ve hatalarla dolu olarak tasvir etti. Buna ek olarak, ona göre İslam, kutsal olmayan, insan yapımı bir doktrin, sapkınlıkların toplamı ve benzeri olarak tanımlandı. Kısacası, Peter Muhammed'e ve İslam'a karşı çok olumsuz bir dil kullandı. Peter, savaşmak yerine, Kuran ve diğer önemli İslami eserleri tercüme ettirip çürüterek Hıristiyanların çıkarlarını Müslümanları dönüştürmeye yönlendirmeye çalıştı. Amacının iki temel ilkeyi uygulamak olduğu düşünülmektedir: İslam hakkındaki cehaleti ortadan kaldırmak ve İslami değerleri çürütmek. Peter'in sözlere ve akla, Müslümanları sevmeye ve misyonlara davet etmesi Francis of Assisi ile yeni bir boyut kazandı. Assisili Francis, bir Roma Katolik rahibiydi ve Fransisken olarak bilinen tarikatın kurucusuydu. Francis of Assisi'nin yaklaşımı çağdaşları arasında farklı bir yere sahipti. Askeri güçlerin yerini Francis ve kardeşleriyle misyoner faaliyetler aldı. 0 , Müslüman dünyasına misyonerlik faaliyetleri yoluyla geçişin kilit bir figürü gibi görünmektedir. Bu nedenle, bazı araştırmacılar ve akademisyenler onu dinler arası diyalog, insan özgürlügü için bir model, barışçll haçlı, Müslümanların dostu gibi vasıflarla adlandırmıştır. Diğer bazıları ise Assisi'nin Müslümanların dostları için bir model değil, misyonerlik faaliyetleri ve Müslümanların din değiştirmesi için bir model olduğunu söylemişlerdir. Mücadele yerine insanların kalbini kazanmaya çalışan Francis, barış yapmaya ve Hıristiyan misyonerliğini dünyanın her yerinde, özellikle Müslümanlara ve Müslüman dünyasına yaymaya karar verdi. Francis, Ortadoğu'da misyonerlik vilayeti kurmak ve Kutsal toprakları Müslüman yönetiminden kurtarmak istedi. Amacı önemli olmakla birlikte amacına ulaşmak için uyguladığı metodoloji amacından daha önemlidir. Çünkü şiddet yerine yeni bir yaklaşımın, barışçıl bir tavrın öncüsü olmuş ve 
bu yaklaşımın başarısını Müslümanlar arasında yaşayarak göstermeye çalışmıştır. Francis of Assisi tarafından başlatılan Fransisken hareketi, şefkat ve kazanılan kalplere dayanan bir diyaloğu vurgularken, Dominikliler aklı kazanmayı amaçladı. Orta Çağ'ın önde gelen Dominikli ve en büyük Hıristiyan ilahiyatçısı Thomas Aquinas, İslam'ı arkadaşlarından, daha önceki Hıristiyan yazılarından, Farabi, İbn Sina ve İbn Rüşd'ün eserlerinden öğrendi. Aquinas, bilimsel misyonerlik faaliyetlerinde bulunmuş ve haçlların Müslümanlara karşı tutumunu desteklemiş ve olumsuz bir duruş sergilemiştir. Müslümanları ve diğer kâfirleri tek düşman olarak gören Aquinas, Müslümanlara karşı ilk misyonerlik kitabı olan küçük bir risale yazmıştır. Bu kitabı yazmasının temel nedeni, Müslüman topraklarda yaşayan Hıristiyanların din değiştirme faaliyetlerine yardımcı olmaktı. Fransiskenlerin misyonerlik çalışmalarına entelektüel bir yaklaşım sergileyen Aquinas'ın başlangıç noktası şuydu: "İçinizdeki umut ve inancın nedenini size soranlara her zaman yanit vermeye hazır olun" Bu, Thomas Aquinas'ın "inancı kanitlamaktan ziyade Hiristiyan inancının makul olduğunu göstermek" felsefesini yansitmaktadır. Savaşa muhalefetine rağmen bunu Müslümanlara karşı kötü bir dil kullanarak ispatlamaya çalışmıştır. Ek olarak Aquinas, Muhammed'e ve İslami değerlere hakaret ederek Peter gibi daha öncekilerin yolunu takip etmiştir. Dolayısıyla Aquinas, bilimsel misyonerlik faaliyetlerinde bulunması ve bunu desteklemesinin yanı sıra haçlıların Müslümanlara karşı sergiledikleri yaklaşım tarzına da sıcak bakmamıştır.

Anahtar Kelimeler: Dinler Tarihi, İslam, Bernard of Clairvaux, Peter the Venerable, Francis of Assisi, Thomas Aquinas.

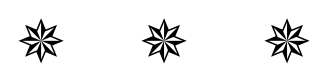

